\title{
Stability of YKL-40 concentration in blood samples
}

\author{
E. V. S. HØGDALL ${ }^{* \dagger} \dagger$ J. S. JOHANSEN, + S. K. KJAER, ${ }^{*}$ P. A. PRICE, \\ J. BLAAKJAER \& C. K. HØGDALL\#
}

*Division for Cancer Epidemiology, Danish Cancer Society, Copenhagen, Denmark, $\dagger$ Laboratory of Molecular Biology, Statens Serum Institute, Copenhagen, Denmark, $\$$ Department of Rheumatology, Hvidovre Hospital, University of Copenhagen, Denmark, §Department of Biology, University of California San Diego, La Jolla, California, USA, Department of Gynaecology \& Obstetrics, Aarhus University Hospital, Skejby, Denmark and \#The Gynaecologic Clinic, The Juliane Centre, Rigshospitalet, Copenhagen, Denmark

Høgdall EVS, Johansen JS, Kjaer SK, Price PA, Blaakjaer J, Høgdall CK. Stability of YKL-40 concentration in blood samples. Scand J Clin Lab Invest 2000; 60: 247-252.

The stability of YKL-40, a mammalian member of the family of 18 glycosylhydrolases, in blood samples handled under different temperatures and different time intervals before centrifugation was studied in paired serum and plasma samples from 25 healthy premenopausal Danish women. Significant elevations of YKL-40 were found in 8 paired serum samples left on the clot for more than $3 \mathrm{~h}$ at room temperature compared to paired serum samples left on the clot for $3 \mathrm{~h}$ or less. Significant elevations of YKL-40 were found in 8 paired plasma (EDTA) samples left on the blood cells for more than $8 \mathrm{~h}$ at room temperature compared to paired plasma (EDTA) samples left on the blood cells for $8 \mathrm{~h}$ or less. No elevations were found in YKL-40 levels in serum samples left on the clot at $4{ }^{\circ} \mathrm{C}$ for $24 \mathrm{~h}$ or in plasma (EDTA) samples left on the blood cells for $72 \mathrm{~h}$ before centrifugation. Significantly lower concentrations of YKL-40 were measured in plasma (EDTA) compared with paired serum samples with a serum/plasma ratio of 1.4 in samples left on the clot or on blood cells at $4^{\circ} \mathrm{C}$ for up to $24 \mathrm{~h}$. Repetitive freezing and thawing had no significant effect on the measured YKL40 concentrations. In conclusion, we have shown that YKL-40 is very dependent on the handling procedures. All the blood samples must be processed into plasma (EDTA) within $8 \mathrm{~h}$ at room temperature or into serum in less than $3 \mathrm{~h}$ at room temperature. If this is not possible, the blood samples must be stored at $4^{\circ} \mathrm{C}$ until processed.

Key words: ELISA; plasma; serum

Estrid Hogdall, Division for Cancer Epidemiology, Danish Cancer Society, Strandboulevarden 49, DK-2100, Copenhagen Ø, Denmark.

E-mail.hogdall@dadlnet.dk or estrid@cancer.dk 


\section{INTRODUCTION}

YKL-40 is a member of the 18 glycosylhydrolase family $[1,2]$, a protein family which includes chitinases and chitinase-related proteins. YKL-40 is a lectin that binds chitin [3] and heparin [4], but it has no chitinase activity $[2,3]$. The protein has been termed YKL-40 from its molecular weight $(40 \mathrm{kDa})$ and the one-letter code for its three N-terminal amino acids [5] and is also named human cartilage glycoprotein-39 [2]. The sequence of the gene has been published, but promotor analysis and regulatory factors have not been described [6]. Although the physiological function of YKL-40 is unknown, the pattern of its expression in the normal and disease state suggests a role in remodelling or degradation of the extracellular matrix. YKL-40 is secreted in large amounts in vitro by the MG63 human osteosarcoma cell line [5] and as a protein expressed by murine mammary tumours initiated by neu/ras oncogenes [7].

Recently, it has been demonstrated that the serum YKL-40 level is elevated in patients with colorectal cancer and in patients with recurrent metastatic breast cancer compared to the YKL-40 level in healthy controls. In both studies a significant association between increased serum YKL-40 level and short survival was found. Serum YKL-40 may therefore be used as a prognostic biochemical marker of survival $[8,9]$. We therefore planned to include YKL-40 measurement in an ovarian cancer study. Because the study involved blood sampling at different hospitals and transport of the blood samples to a central laboratory, we undertook this study to assess the stability of YKL-40 in the 1-3 day time period required for postal delivery.

\section{MATERIALS AND METHODS}

\section{Subjects}

The study population consisted of 25 healthy premenopausal women from Denmark. The blood samples were collected in three different sets. One set consisted of serum samples from 8 women (set A), another of serum and paired plasma samples (EDTA and heparin) from 9 women (set B), and a third set of serum and plasma (EDTA) samples from 8 women (set C). The collection tubes, the storage temperature before centrifugation and the length of storage before centrifugation were changed between the different groups of samples. All samples were then centrifuged at $2000 \times g$ for $10 \mathrm{~min}$, and the plasma or serum samples were stored at $-20^{\circ} \mathrm{C}$ until YKL-40 analysis was performed. In addition, to investigate the effect of repetitive thawing and freezing the serum from 9 women (set B) was divided into 8 aliquots and frozen within $1 \mathrm{~h}$ from venipuncture. After $24 \mathrm{~h}$, seven aliquots from each woman were thawed at room temperature and refrozen after $1 \mathrm{~h}$. This process was repeated daily, leaving one aliquot frozen each day, until the last aliquot was thawed and refrozen after 7 days before YKL-40 analysis.

\section{Laboratory analysis}

Serum and plasma YKL-40 concentrations were determined in duplicates using an ELISA system developed by Harvey et al. [10] in accordance with the manufacturer's instruction (Metra Biosystems, Mountain View, CA, USA). The sensitivity of the assay was $20 \mu \mathrm{g} \mathrm{L}^{-1}$ and the intra- and interassay variations were $3.6 \%$ and $5.3 \%$, respectively $(n=67)$.

\section{Statistical analysis}

All distributions were examined for normality before the application of parametric analyses. A paired $t$-test was used for data examination.

\section{RESULTS}

At room temperature a minor decrease in YKL-40 mean level in 8 plasma (EDTA) samples (set C) left on the blood cells for $3 \mathrm{~h}$ was seen compared to samples left on the blood cells for $1 \mathrm{~h}(p=0.05)$. In contrast, a non-significant increase was found in plasma (EDTA) samples left on the blood cells for $8 \mathrm{~h}$ at room temperature before separation compared to samples left for $1 \mathrm{~h}$ $(p=0.77)$. For plasma (EDTA) samples left on blood cells at room temperature for 24 and $72 \mathrm{~h}$ before plasma pipetted off the blood cells, the increases in the YKL-40 levels were significant compared to samples left on the 
TABLE I. YKL-40 levels $\left(\mu \mathrm{g} \mathrm{L}^{-1}\right)$ in plasma (EDTA) left on the blood cells at respectively $4{ }^{\circ} \mathrm{C}$ and at room temperature $\left(24^{\circ} \mathrm{C}\right)$ for $1 \mathrm{~h}, 3,8,24$ and $72 \mathrm{~h}$ before samples are centrifuged and plasma pipetted off the blood cells (set C).

\begin{tabular}{lcccccccccc}
\hline Temperature & \multicolumn{1}{c}{$4{ }^{\circ} \mathrm{C}$} \\
\hline Hours clotting & 1 & 3 & 8 & 24 & 72 & 1 & 3 & 8 & 24 & 72 \\
Mean & 25.4 & 26.0 & 25.8 & 26.9 & 26.6 & 25.5 & 24.1 & 25.8 & 32.0 & 36.6 \\
Range & $20-35$ & $20-37$ & $20-36$ & $20-38$ & $20-37$ & $20-36$ & $20-34$ & $20-38$ & $21-45$ & $23-53$ \\
SD & 5.4 & 5.9 & 5.5 & 6.4 & 6.4 & 5.7 & 4.7 & 6.0 & 8.7 & 10.3 \\
$P$ values* & & 0.57 & 0.68 & 0.16 & 0.18 & & 0.05 & 0.77 & 0.003 & 0.002
\end{tabular}

Number of samples repetitively analysed $=8 . \mathrm{SD}=$ standard deviation. $*$ The $p$ values are the significance levels between plasma at $1 \mathrm{~h}$ and the actual samples at $3,8,24$ or $72 \mathrm{~h}$.

blood cells for only $1 \mathrm{~h}$ ( $24 \mathrm{~h}: p=0.003$; and $72 \mathrm{~h}: p=0.002$ ) (Table I). There were no significant changes in YKL-40 levels in plasma (EDTA) samples left on the blood cells at $4{ }^{\circ} \mathrm{C}$ for respectively $3,8,24$ and $72 \mathrm{~h}$ compared to samples left on the blood cells for $1 \mathrm{~h}$ (3 h: $p=0.57 ; 8$ h: $p=0.68 ; 24 \mathrm{~h}: p=0.16$; and $72 \mathrm{~h}: p=0.18$ ) (Table I).

A small increase in serum YKL-40 concentrations was observed in 8 samples (set A) left on the clot at room temperature for $3 \mathrm{~h}$ $(p=0.054)$, but the elevation in serum YKL40 was highly significant after $72 \mathrm{~h}(p=0.004)$ compared with paired serum samples separated by centrifugation followed by pipetting off the clot $1 \mathrm{~h}$ after venipuncture (Table II). No difference was found in serum YKL-40 levels between samples left on the clot at $4{ }^{\circ} \mathrm{C}$ for $1 \mathrm{~h}$ and $3 \mathrm{~h} \quad(p=0.13) \quad$ (Table II). Significant increases were found in serum YKL-40 levels when samples left on the clot at $4{ }^{\circ} \mathrm{C}$ for $1 \mathrm{~h}$ were compared to paired samples left on the clot at $4^{\circ} \mathrm{C}$ for $72 \mathrm{~h}(p=0.007)$ (Table II). In the third set of samples from 8 healthy women (set C) the serum YKL-40 levels were stable in samples left on the clot at $4{ }^{\circ} \mathrm{C}$ for $8 \mathrm{~h}$ and $24 \mathrm{~h}$ compared to samples centrifuged and pipetted off the clot after $1 \mathrm{~h}(8 \mathrm{~h}: p=0.32$; and $24 \mathrm{~h}$ : $p=0.15$ ). In the paired samples left on the clot at room temperature, significant increases in serum YKL-40 levels were found after $8 \mathrm{~h}$ $(p=0.001)$ and $24 \mathrm{~h}(p=0.001)$ compared to samples left on the clot for only $1 \mathrm{~h}$ before centrifugation and separation off the serum from the clot by pipetting.

YKL-40 levels were significantly higher in serum compared to paired plasma samples (serum vs. EDTA plasma: 55.8 vs. $38.8 \mu \mathrm{g}$ $\mathrm{L}^{-1}, p=0.003$; and serum vs. heparin plasma: 55.8 vs. $\left.43.8 \mu \mathrm{g} \mathrm{L}^{-1}, p=0.004\right)$ centrifuged after $1 \mathrm{~h}$ at room temperature. The lowest YKL-40 levels were found in EDTA plasma compared to the corresponding serum or heparin levels. The serum/plasma ratio of YKL-40 was 1.4 after $1 \mathrm{~h}, 8$ and $24 \mathrm{~h}$ at $4{ }^{\circ} \mathrm{C}$, but increased in serum and plasma samples that had been left on the clot or left on the blood cells at room temperature for 8 and $24 \mathrm{~h}$ (Table III).

Repetitive freezing and thawing of the serum up to eight times did not significantly affect the serum YKL-40 levels in paired samples (set B) (Table IV).

TABLE II. YKL-40 levels $\left(\mu \mathrm{g} \mathrm{L}^{-1}\right)$ in serum samples left on the clot at $4{ }^{\circ} \mathrm{C}$ and at room temperature $\left(24^{\circ} \mathrm{C}\right)$ in $1 \mathrm{~h}, 3$ and $72 \mathrm{~h}$ before separation off the serum from the clot (set $\mathrm{A}$ ).

\begin{tabular}{lcccccc}
\hline Temperature & \multicolumn{3}{c}{$4{ }^{\circ} \mathrm{C}$} & \multicolumn{2}{c}{$24^{\circ} \mathrm{C}$} \\
\hline Hours clotting & 1 & 3 & 72 & 1 & 3 & 72 \\
Mean & 49.3 & 44.9 & 54.8 & 50.3 & 53.1 & 97.3 \\
Range & $20-111$ & $20-98$ & $20-118$ & $20-111$ & $20-113$ & $20-158$ \\
SD & 30.26 & 26.28 & 30.99 & 30.17 & 30.38 & 49.06 \\
$P$ values* & & 0.13 & 0.007 & & 0.054 & 0.004 \\
\hline
\end{tabular}

Number of samples repetitively analysed $=8 . \mathrm{SD}=$ standard deviation. $*$ The $p$ values are the significance levels between serum at $1 \mathrm{~h}$ and the actual samples at $3 \mathrm{~h}$ or $72 \mathrm{~h}$. 
TABLE III. The ratios of YKL-40 levels $\left(\mu \mathrm{g} \mathrm{L}^{-1}\right)$ in serum compared to plasma (EDTA) separated off the clot or off the blood cells after respectively $1 \mathrm{~h}, 8$ and $24 \mathrm{~h}$ at $4{ }^{\circ} \mathrm{C}$ and at room temperature $\left(24^{\circ} \mathrm{C}\right)$.

\begin{tabular}{lcccccc}
\hline Temperature & \multicolumn{3}{c}{$4{ }^{\circ} \mathrm{C}$} & \multicolumn{2}{c}{$24^{\circ} \mathrm{C}$} \\
\hline Hours clotting & 1 & 8 & 24 & 1 & 8 & 24 \\
Mean ratio & 1.41 & 1.42 & 1.42 & 1.61 & 1.95 & 2.03 \\
Range ratio & $0.83-1.79$ & $1.10-1.83$ & $1.25-1.85$ & $1.25-1.90$ & $1.40-2.74$ & $1.33-2.66$ \\
SD ratio & 0.29 & 0.27 & 0.21 & 0.24 & 0.42 & 0.45 \\
$P$ values* & & 0.93 & 0.92 & & 0.07 & 0.037 \\
\hline
\end{tabular}

Number of samples repetitively analysed $=9 . \mathrm{SD}=$ standard deviation. $*$ The $p$ values are the significance levels between the serum/plasma ratio 8 and $24 \mathrm{~h}$ and the ratio at $1 \mathrm{~h}$.

\section{DISCUSSION}

We found levels of YKL-40 to be sensitive to different handling conditions. In serum left on the clot at $4{ }^{\circ} \mathrm{C}$ the YKL-40 levels were stable for up to $24 \mathrm{~h}$, but after $72 \mathrm{~h}$ the serum level was significantly increased. The YKL-40 levels were stable in plasma (EDTA) left on the blood cells for $72 \mathrm{~h}$ when stored at $4^{\circ} \mathrm{C}$ before centrifugation followed by plasma pipetted off the blood cells. The most important finding of the present study was seen in blood samples left at room temperature before separation into serum or plasma by centrifugation. We found significant increases in YKL-40 levels in serum $(55 \%$ increase) and in plasma (EDTA) $(25 \%$ increase) left for $24 \mathrm{~h}$ before separation compared to the levels in serum and plasma samples left on the clot or left on the blood cells for $1 \mathrm{~h}$ at room temperature before separation. These findings may seriously influence the specificity of YKL-40 in clinical studies, where the samples are transported from the sampling place to a central laboratory. Blood samples drawn for the YKL-40 analysis should therefore be processed into serum within $3 \mathrm{~h}$ or for EDTA-plasma samples in less than $8 \mathrm{~h}$. If the blood samples have to be transported for a longer time period before centrifugation and separation of serum or plasma, the samples should be stored and shipped at $4^{\circ} \mathrm{C}$.

The most likely explanation for the timedependent increase in YKL-40 levels at room temperature is that a degranulation of neutrophils occurs in the blood sample. YKL-40 is present in the specific granules of human neutrophils isolated from the blood of healthy subjects [11] and is released from these granules by exocytosis. It is well known that neutrophils degranulate in blood samples during prolonged storage and release the proteins in the granules $[12,13]$. The YKL-40 levels were higher in serum compared to plasma (EDTA and heparin) and this is in accordance with other studies that have reported significantly higher levels of lactoferrin and neutrophil gelatinaseassociated lipocalin NGAL (proteins present in the specific granules of neutrophils) in serum compared with plasma [13]. The differences between serum and plasma YKL-40 levels have to be considered when reference intervals are established in future studies.

Serum samples were stable on repetitive freezing and thawing up to eight times. This is re-assuring, as in many studies the samples are frozen for later analysis. Commonly, frozen serum samples also may have been thawed and frozen several times for other analyses when

TABLE IV. The influence of freezing and thawing on the YKL-40 serum levels $\left(\mu \mathrm{g} \mathrm{L}^{-1}\right)$ (set B).

\begin{tabular}{lcccccccc}
\hline No. of freeze cycles & 1 & 2 & 3 & 4 & 5 & 6 & 7 & 8 \\
\hline Mean YKL-40 & 55.8 & 52.1 & 52.8 & 53.1 & 52.6 & 55.0 & 51.4 & 53.6 \\
Range & $30-82$ & $30-91$ & $33-78$ & $30-85$ & $30-80$ & $33-91$ & $28-84$ & $32-84$ \\
SD & 15.73 & 17.67 & 12.32 & 16.14 & 14.62 & 18.33 & 15.73 & 15.45 \\
$P$ values* & & 0.21 & 0.15 & 0.20 & 0.25 & 0.81 & 0.13 & 0.42 \\
\hline
\end{tabular}

Number of samples repetitively analysed $=9 . \mathrm{SD}=$ standard deviation. $*$ The $p$ values are the significance levels between one freezing and the actual freezing number (e.g. No. 1 vs. No. 5: $p=0.25$ ). 
new tumour marker assays appear. Earlier and future YKL-40 studies performed on correctly processed, frozen and thawed samples will still be trustworthy.

\section{ACKNOWLEDGMENTS}

This work was supported by grants from the Danish Cancer Society, Det Obelske Familiefond, Michaelsen Fonden and "Else og Mogens Wedell-Wedellsborg fond". The expert technical assistance of Vibeke Reese and Connie Kjeldkvist, Department of Clinical Biochemistry, Statens Serum Institute and Susanne Munch and Inger Aakaard, Department of Rheumatology, Hvidovre hospital is greatly appreciated.

\section{REFERENCES}

1 Johansen JS, Jensen HS, Price PA. A new biochemical marker for joint injury. Analysis of YKL-40 in serum and synovial fluid. $\mathrm{Br} \mathrm{J}$ Rheumatol 1993; 32: 949-55.

2 Hakala BE, White C, Recklies AD. Human cartilage gp-39, a major secretory product of articular chondrocytes and synovial cells, is a mammalian member of a chitinase protein family. J Biol Chem 1993; 268: 25803-10.

3 Renkema GH, Boot RG, Au FL, DonkerKoopman WE, Strijland A, Muijsers AO, Hrebicek M, Aerts JM. Chitotriosidase, a chitinase, and the 39-kDa human cartilage glycoprotein, a chitin-binding lectin, are homologues of family 18 glycosyl hydrolases secreted by human macrophages. Eur J Biochem 1998; 251: 504-9.

4 Shackelton LM, Mann DM, Millis AJ. Identification of a $38-\mathrm{kDa}$ heparin-binding glycoprotein (gp38k) in differentiating vascular smooth muscle cells as a member of a group of proteins associated with tissue remodeling. J Biol Chem 1995; 270: $13076-83$.
5 Johansen JS, Williamson MK, Rice JS, Price PA. Identification of proteins secreted by human osteoblastic cells in culture. J Bone Miner Res 1992; 7: 501-12.

6 Rehli M, Krause SW, Andreesen R. Molecular characterization of the gene for human cartilage gp-39 (CHI3L1), a member of the chitinase protein family and marker for late stages of macrophage differentiation. Genomics 1997; 43: $221-5$.

7 Morrison BW, Leder P. neu and ras initiate murine mammary tumors that share genetic markers generally absent in c-myc and int-2initiated tumors. Oncogene 1994; 9: 3417-26.

8 Johansen JS, Cintin C, Jorgensen M, Kamby C, Price PA. Serum YKL-40: a new potential marker of prognosis and location of metastases of patients with recurrent breast cancer. Eur J Cancer 1995; 31A: $1437-42$.

9 Cintin C, Johansen JS, Christensen IJ, Price PA, Sorensen S, Nielsen HJ. Serum YKL-40 and colorectal cancer. Br J Cancer 1999; 79: 1494-9.

10 Harvey S, Weisman M, O'Dell J, Scott T, Krusemeier M, Visor J, Swindlehurst C. Chondrex: new marker of joint disease. Clin Chem 1998; 44: 509-16.

11 Volck B, Price PA, Johansen JS, Sorensen O, Benfield TL, Nielsen HJ, Calafat J, Borregaard N. YKL-40, a mammalian member of the chitinase family, is a matrix protein of specific granules in human neutrophils. Proc Assoc Am Phys 1998; 110: $351-60$

12 Kjeldsen L, Bjerrum OW, Hovgaard D, Johnsen AH, Sehested M, Borregaard N. Human neutrophil gelatinase: a marker for circulating blood neutrophils. Purification and quantitation by enzyme linked immunosorbent assay. Eur J Haematol 1992; 49: 180-91.

13 Lollike K, Kjeldsen L, Sengelov H, Borregaard N. Lysozyme in human neutrophils and plasma. A parameter of myelopoietic activity. Leukemia 1995; 9: $159-64$.

Received: 29 November 1999

Accepted: 14 January 2000 